\title{
Work-based assessment at vocational high school in Indonesia
}

Santosa, Budi

Ahmad Dahlan University, Indonesia (budi.santosa@mpv.uad.ac.id)

Dwi, Sulisworo $\$

Ahmad Dahlan University, Indonesia (sulisworo@gmail.com)

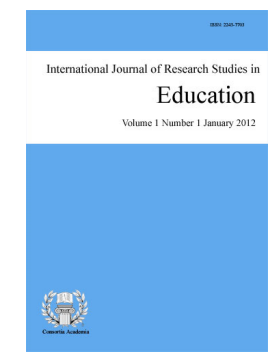

ISSN: 2243-7703 Online ISSN: 2243-7711

\section{Abstract}

The purpose of this paper is to discuss the problems of applying competence based assessment in vocational high school when student learning in the workplace. This research method is research and development. Respondents are students, teachers, industry counselors and assessors of professional certification bodies coming from four schools and four workshops. The original construction of the work-based assessment is based on an integration of learning processes in schools and industry work practices in the studio. Work-based assessment is conducted by developing; competency standards, learning at school and workplace when students are learning at industrial work practices. Vocational secondary schools must have a professional certification body, a competency test site, and independent assessors. The development of competency standards is done by combining the competency standards of graduates in schools with competency needs in the industry. The model of work-based assessment that is proposed appears to have a reasonable level of the implement to industry work practices for the student and provides an approach to describing the training that is not limited to learning contexts.

Keywords: work-based assessment; competence based assessment; workplace; vocational education; innovation; professional 


\section{Work-based assessment at vocational high school in Indonesia}

\section{Introduction}

The purpose of this study is to develop a model of competency-based assessment/CBA that combines the development of competency standards, curriculum, competency-based learning and industrial work practices in a linkage. In detail, this study aimed to develop a model of work-based assessment/WBA in Vocational High School (VHS) students' automotive light vehicle engineering expertise competence from the aspect of learning in VHS and industry work practices in the business/industry. The competency-based assessment currently performed by VHS students requires considerable cost and time, as they are done separately in each competency.

VHS aims to prepare students to enter employment and develop professional attitudes, be able to choose careers, compete, and develop themselves, becoming a middle-level workforce to fill the needs of business and industry. Dewey (1916) argues that: a vocation means nothing to a person, because of the consequences they accomplish, and also useful to his associate. Meanwhile, Prosser (1925) states that vocational education will be helpful if done through work environment, industry standard and work habit. Students work in the working environment with industry standard and have good working behavior.

DiRanna (2008) states that the paradigm shift in teaching and learning begins with an assessment. This idea suggests that the harmony between curriculum, knowledge, and judgment leads to better understanding of the pupil. This means that an inseparable link between curriculum, learning, and assessment can improve students 'and teachers' knowledge to teach well. Competency-based assessment (CBA) according to Fletcher (2000) is referring to work rules and to obtain work competency standards. CBA as an approach to setting competency standards relevant to work-related, its emphasis on competence demonstrated in essential skills in a job (Hawke, 1998). According to the two opinions above, the reference in the competency-based assessment uses the standard of work competence and relevance to the world of work.

According to Halliday (2012), the competency test in vocational education has two essential elements, namely the collection of evidence of the ability of each student and using that evidence to make decisions about whether the student has reached a standard of competence as defined nationally or as contained in the curriculum used. While SAQA (2005) stated that to conduct an integrated competency test must be supported by teaching and learning activities in an integrated way as well and to combine learning and competency test conducted by developing curriculum. So between teaching, learning and competency test is an activity that can be designed as an interrelated process. This implies that curricula and learning programs need to be developed in an integrated manner.

The CBA was conducted at VHS in Indonesia currently uses a non-employment assessment scheme. Students who have completed practical learning in the school workshop and industry, are assessed by the school in collaboration with industry or by professional certification bodies. This CBA model is less efficient because students follow competency test based on competency cluster separately. Work-based assessment/WBA is an integrative CBA because students as assessed perform a real job in the workshop when carrying out industrial work practices.

\section{Research methodology}

This study aims to develop a model of competency-based assessment at VHS and is intended to produce products in the form of a work-based assessment model in VHS. This research method is research and development (R\&D) developed by Gall (Gall, 2007). R\&D research is a process used to create and validate educational products. Respondents consisted of teachers, mentors of industry work practices, students and assessors of professional certification agencies from four schools and four auto/industry workshops. 
The R\&D research step according to Gall that has been modified by Nana Syaodih Sukmadinata (2011: 184-190) consists of three phases. The first step is a preliminary study comprised of literature study and drafting of competency test product. Literature study is done by examining the aspects studied, whether derived from the study theory, research results, or field studies related to the competency test. Preparation of competency test product draft conducted based on the literature study and expert judgment through focus group discussion (FGD) with experts/academicians and practitioners of educational institutions and industry/associations. The second step is product development which consists of a limited product trial, analysis of test results, and expanded trials. An examination of limited product conducted on two (2) VHS. The study is done by compiling the results of the product try limitedly. The extended product trial was held on four (4) VHS. The third step is a test consisting of final product testing and outcome socialization.

Field studies were conducted to collect data related to the competency test. Field surveys were conducted at Yogyakarta VHS, and in industry. Field surveys in the form of preliminary study in VHS conducted in public VHS and private VHS. Public VHS implemented in SMK Negeri 2 Yogyakarta, and single VHS held at SMK Perindustrian Yogyakarta. Field surveys in the industry are conducted at the Kalimas Workshop (Mercedes Benz Training Center) Yogyakarta and the Institute of Automotive Engineering / LSPTO Yogyakarta. Data collection is done through questionnaires, interviews, documentary studies and observations during the implementation of learning in SMK, on-the-job training (OJT), and competency-based assessment.

The components of the developed model consist of; (a) development of competency standards, (b) curriculum development, (c) development of learning, (d) development of industrial work practices, and (e) development of competency tests. The contents of each component are as follows:

$>$ Development of competency standards, Indonesian national competence standards (Standar Kompetensi Kerja Nasional Indonesia/SKKNI) and industry needs become a reference in formulating competency standards.

> Curriculum development, VHS, and partner institutions develop curriculum through curriculum synchronization by integrating existing competencies in SKKNI and curriculum spectrum from educational ministry. Education unit level curriculum is a blend of competency standards of graduates \& national standard of education from the educational department with SKKNI.

$>$ Development of practical learning in VHS, teachers, are required to have technical competence certificates according to the subjects that are taught and as well as teachers as independent assessors in engineering, competency-based learning model, students using modules, students are provided with soft skills in the form of VHS and skills passport.

$>$ Development of industrial work practices (IWP), students selecting competency clusters with industry permission, students working/studying according to their chosen competency cluster, assessment is done through competency test when students work with competent or incompetent outcomes as junior mechanics in the competency cluster of their choice.

$>$ Development of competency-based assessment, competency-based assessment is done on real job when IWP, teacher as assessor, skills passport becomes proof of ownership of student competence, VHS has CBA centre, VHS has first-party certification bodies (Lembaga Sertifikasi Profesi Pihak Pertama/LSPP-1, LSPP-1 as an independent institution under national agency for professional certification (Badan Nasional Sertifikasi Profesi/BNSP) conducts competency test through two channels, namely competency test with real work when IWP student in industries, and simulation competency test, $L S P P-1$ issued competency certificate.

The research and development procedure is carried out in three stages: (1) preliminary study, (2) model development, and (3) model test. This research and development step can be described as follows. The first step is 
a preliminary study which contains: (1) literature study on the aspects studied, whether from theory study, research result, or field study related to competency test, and (2) preparation of product competency test draft conducted based on literature studies and expert judgment through focus group discussions with academics and practitioners of educational institutions and industry/associations. The second step is product development consisting of: (1) a limited product trial conducted on two VHS, and (2) an extended product trial conducted on four VHS. The third step is a test consisting of final product testing and outcome socialization.

\section{Results and discussions}

The results of in-depth interviews with practitioners, academics, and industry were analyzed and guided in the discussion. Gulikers (2017) state that was building up practical knowledge of competencies and how to assess them should be at the heart of future interventions and professional development. The discussion includes the aspects of the development of competency standards, curriculum development, development of learning in VHS and industry, development of assessment on VHS in Yogyakarta.

\subsection{Development of Competency Standards}

The competency standard in vocational education is developed based on a combination of SKKNI in the field of automotive sub-field of light vehicle engineering with competency standard of graduates of curriculum from Kemendikbud covering aspects of knowledge, attitude, and skill. SKKNI used as a guide in developing competence in the VHS standard for educational purposes in VHS is preparing students for work. Norton (2008) mentions that in the analysis of standard tasks begins with job needs analysis and ends with the development of a competency profile. Norton's opinion suggests that in the event of competency standards it is necessary to do job needs analysis, which is stated in SKKNI, and developed into a standard of competence. Another opinion expressed by Kelly (2000) says that in formulating basic rules in vocational education, basic concepts and operations and humanitarian, ethical and social aspects should be developed. Norton and Kelly's statement reinforces the need for an alliance between competency standard of graduates and SKKNI in developing competency standards in VHS.

Standards of competence must be tailored to the needs of the world of work and are based on benchmark benchmarks. Arguments supporting the above statement delivered by Lester (2017) and Reeves (2004) which states that an educational approach based on standards including: (a) the criteria are fixed, the intention is that in a system based on the standard, students should be able to conduct a competency determined, (b) rules measure proficiency, ability to do a job/task being the size of the standard system, (c) the rules are challenging, conventional method to test all students to master the knowledge and skills that have been determined/standardized, and (d) rules are simple, the traditional way of educational outcomes is competent or incompetent that is easy to understand. VHS aims to prepare students to enter the work field and develop a professional attitude, develop themselves, and become a middle-level workforce to fill the needs of business and industry. Guided by the goals of education in the VHS, the students are learning standard competency VHS must be adapted to the competence and jobs in the industry.

FGD participants consist of 7 (seven) people comprised of automotive workshop 2 (two) persons, section head of instructor of PT Nasmoco Toyota Janti and Head of PT Sumber Baru Suzuki Mobil, National Automotive Certification Agency/NACA (Badan Nasional Sertifikasi Profesi/BNSP) 1 (one) person namely the master BNSP assessor, and 4 (four) teachers of VHS.

The FGD participants proposed that the standard competency aspect was raised to be a separate aspect so that the Indonesian National Work Competency Standards/NWCS (Standar Kompetensi Kerja Nasional Indonesia/SKKNI) is the basis for the preparation of the VHS curriculum. Issues of curriculum development, competencies learned by VHS students need to be tailored to the needs of the industry. The proposal is in line with Prosser's opinion in Scott (2004: 390-391) which states that vocational education has particular characteristics. First, vocational training will be efficient in proportion as an environment in which students are trained in an 
Work-based assessment at vocational high school in Indonesia

environmental replica in which it will later work. Second, an active vocational school as a training institution should be able to provide the same facilities like those in the world of work. Students can learn to do the same jobs as those in the industry. Students are trained with the skills required by the world of work.

FGD participants also proposed the competency book skill name to be changed into passport skill that contains all the competencies that will be learned by VHS students either at the time of learning in VHS or industry. The competencies studied in VHS are separated by the skills studied/carried out in the industry. The competency standard studied in vocational school is the primary/general competency that must be mastered by the vocational students and working/core competency that is learned in the industry when the students carry out the industrial work practice. The standard of competence referred to is the competency standard listed in the SKKNI.

\subsection{Curriculum Development}

The results of in-depth interviews suggest that education experts/academics in the field of curriculum developers and automotive engineering developers should be involved in curriculum development, in addition to the business and industry elements. Opinions that support the education experts in the field of curriculum developers and automotive engineering fields involved in curriculum development is Norton (2008). Norton stated that the personnel involved in curriculum development consists of; (a) administrators, are academics in the field of vocational education, (b) instructional staff, is the instructor fields of engineering, (c) support personnel, is the developer of curriculum/program, and ( $\mathrm{d}$ ) advisory personnel, is a committee of experts / professional associations. Opinion Norton suggests that members should be involved so that the curriculum can be developed effectively and efficiently is covering the elements of engineering education experts, curriculum developers, and practitioners.

The expert team's suggestion that in developing the curriculum, students' needs and social conditions need to be considered in meeting employment needs in line with Rauner (2009) opinion which states that in the development of a vocational education curriculum; the occupational form of work becomes the point of reference for the development of curricula. Rauner's opinion suggests that in developing a vocational education curriculum, job forms related to positions/tasks become a reference in the development of the curriculum. Other opinions that support students' needs and social conditions need to be considered by Scott (2004) suggesting that vocational education as an educational institution should broaden opportunities for students to learn or work as required.

\subsection{Development of Competence-Based Learning}

The results of input from the expert team, which states that the module as a learning resource needs to be enriched with other learning resources to provide flexibility in enhancing students in accordance with the opinion of Norton (2008) which states that learning should be able to offer programs to individual development and process learning can take place in the workplace. Another opinion that supports the above statement is proposed by Clark and Winch (2007) which states that the principles of vocational education emphasize the benefits of information technology as a source of learning. Technology changes will always be optimized in the vocational learning process. So the source of learning is still enriched with the development of technology. Learning in VHS was developed using modules as one of the learning media and enhanced using information technology as another learning resource.

The learning model needs to be developed toward cooperative learning and following the demands of the curriculum has noted expert judgment and in line with the opinion of Clark and Winch (2007) which states that vocational education has characteristics include: First, the curriculum must demonstrate relevance to the vocational needs. This principle shows that the curriculum of vocational education should be relevant to the needs of the world of work. Basic skills in the industry should be trained to students. The curriculum of vocational education should contain competencies related to their expertise in the world of work. For example, the vocational school curriculum must include at least the auto majors competence engine tune-up, system power transfer, chassis, and automotive electrical systems. Second, knowledge must be able to give way better for the learning process, to 
identify problems and solve the problem. This principle shows that in learning there must be a process of adding knowledge and skills that can be used to solve life problems. This means that the learning process should be able to be the basis of the development of knowledge on an ongoing basis.

Thompson (1973) states that vocational education is built on the following principles: first, it must be for development. This opinion indicates that vocational education should always follow the development of technology in realizing development goals. This can not be avoided because technology is still evolving as the times change. Second, the labor market maintains a balance between the needs of employment and unemployment, and between work and a skilled workforce. This suggests that vocational education as a provider of trained workers can contribute to balancing the need for qualified workers with available jobs. The consequence of this argument is that a professional school should be able to provide trained personnel according to the type of work required. This statement suggests that vocational education should cooperate with the world of work so that it can map the needs of the workforce and train vocational school students as a potential employee to become a skilled workforce. The Thomson opinion supports the expert judgment notes that the model needs to be developed towards learning and cooperative learning following the demands of the curriculum.

The results of expert judgment record were stating that the valuation model should consider the assessment process in line with the opinion of Clark \& Winch (2007) that the principle of in-depth curriculum reflected in an assessment system that aims to record what has been achieved across the learning system. In curriculum planning, it also contains what and how the learning process should be carried out, but also includes what and how the assessment system should be done. Another opinion which states that the assessment requires a method proposed by Miller (2008) and Finch (1999). Assessment is a broader term compared to general tests and procedures that include collecting, synthesizing, and interpreting informal data and formal data. VHS student ratings undertaken during student study at VHS is a form of process assessment.

Essential characteristics of the competency-based educational model according to Gonczi (1998) include: (a) a documented list of competencies accompanied by specific standards and conditions for each skill; (b) at any time the student may be assessed for the achievement of his competence when ready, (c) the learning takes place in the format of the module relating to each competency, (d) the assessment is based on specific standards according to the required competence, (e) the competency test is based on the demonstrated skill, (f) the student can proceed to the unit subsequent competencies if learned competencies have been achieved, (g) student learning outcomes recorded and reported in the competence book. Opinion Gonczi reinforce that competency-based assessment should be supported by a record of competence has been achieved, in this case, recorded in the skills passport.

\subsection{Development of Industrial Work Practices}

Results of interviews with expert judgment on the monitoring and evaluation of the implementation practices of industrial work must always be carried out so that the program can be run efficiently supported by the opinion Streumer (2006) which states that the method of industrial workplace (on the job training/OJT) requires arrangements: (a) their clear training objectives, (b) the need for OJT evaluation to determine the achievement of training objectives. Similar opinion expressed by hide no (2000) which states that the judgments in OJT involves two classifications are interrelated, namely: (1) the content of the learning program that has been analyzed to determine the needs to be met, (2) trainers diagnose the knowledge and skills of participants at the beginning programs related to training content. Industrial work practices as part of the teaching and learning process undertaken in the industry need to be supplemented by an evaluation program. Evaluation of industrial work practices in the competency test model is done through work, which means that when the students work industry practices, also conducted an assessment. Students who can carry out the work according to industry standards declared competent in that field.

Results of interviews with expert judgment which states that the program working practices industry there should be standardization of competence along with their performance criteria imposed in the workshop where the 
Work-based assessment at vocational high school in Indonesia

students practice the industrial work was supported by the opinions Streumer (2006) which states that learning in the workplace based on the design of training as detailed in the theory of instructional design. Training objectives are established based on workplace task analysis and learning materials developed following conditions in the work environment. Standardization of competence along with their performance criteria program to VHS students works in industry practices outlined in the skills passport.

Halliday (2012) in his research on the competency test in the workplace found that the assessor and trainer involved in the study agreed that the competency test approach is the thorough and complete way through the clustering method in the competency test. This approach also helps students to consider what is essential in learning as fundamental principles and concepts, the relationship between ideas and the relationship of new concepts with prior knowledge. In this study, the assessor and trainer also believe that it is an essential method for students to clearly understand the context of that training and competency testing is all in one place. Halliday's opinion is reinforced that when students carry out working in industry competence test can be done. The findings of the assessors who are less familiar with this competency test system following the opinion of Haines (2013), so that the requirements to become assessor is must have been certified as assessors.

The objectives of dual system education (pendidikan system ganda/PSG) by Depdikbud (1999) are: (1) to improve the quality and relevance of vocational education through the participation of partner/industry, (2) to produce graduates with knowledge, skills and work ethics in accordance with job demands, 3) to provide graduates who have the knowledge, skills, and attitudes on which to base their own sustainable development, (4) recognize and reward work experience as part of the education process, and (5) improve the efficiency of vocational secondary education through the utilization of resources education in the world of work. Two last statement suggests that $P S G$ in the form working in industry program can be used to give recognition and appreciation of the work experience as part of the educational process and to improve the efficiency of vocational education.

\subsection{Development of Work-Based Assessment/WBA}

Haines (2013, p. 135) states that WBA can drive learning in context and ensure clinical standards are maintained. Haines's opinion reinforces that the work-based assessment associated with the learning process can be done well. According to the expert judgment, the existence of the CBA center and LSPP- 1 on VHS developed should be supported by substantial policies and regulations. This opinion is reinforced by Dedi Supriadi (2002) who stated that one of the principles of vocational education in measuring the learning outcomes should be done by an independent institution based on competence standards applicable in the industry. A similar opinion was stated by Depdikbud (1997) which says that the process of skill testing is carried out by national bodies. The competency test in VHS needs to be carried out by professional certification bodies recognized by professional certification bodies in order to gain recognition from independent institutions. According to the guidelines of the BNSP, education and training institutions may seek the existence of $L S P P-1$. VHS students are tested by $L S P P-1$ that accredited by $B N S P$.

Competency-based assessment is collecting evidence of competence done by assessors who have authority. According to Halliday (2012) and Hayes (2012), the CBA in vocational education has two essential elements, namely the collection of evidence of the ability of each student and using that evidence to make decisions about whether the student has reached a standard of competence as defined nationally or as contained in the curriculum used. Competence which has owned the VHS students when carrying out work in an industry and has been recorded in the skills passport can serve as a proof of competency testing process. Competency-based assessment in the form of evidence of competence is conducted by LSPP-1. Students who have fulfilled the competence requirements are deemed to have been competent and certified by LSPP-1. Students who have not been declared competent for evidence of competence is not yet eligible and students who want to gain competencies can follow competency test in LSPP-1 with using the pattern through the work/simulation. Students who have met all competency package will receive a certificate as a technician junior lightweight vehicles and for those who do not meet the appropriate competency will receive a certificate that has mastered the skills contained in the passport. 


\section{Conclusion}

Learning component to support the implementation of work-based assessment model are: (a) the teacher must have a certificate of competence and become independent assessor, (b) a competency-based learning model, (c) students equipped with the soft skills of students through the material ber-Kaizen, (d) passport validated ability be a guide to achieve competence and at the same time be evidence of achievement of competencies, (e) VHS has CBA center, (f) VHS became independent professional certification agency in the form of LSPP-1.

Components working practices industry that can support the implementation of a test model of competency-based work are: (a) students must have necessary skills such as that contained in the skills passport,(b) students choose the location where the practice has had a Memorandum of Understanding with the school, (c) students do observation in the preparation, make a selection focus of the work / clusters of competence and approved by the industry, (d) VHS assigning students to carry out prakerin according to the results approval of the industry, (e) a competency test done through the work of real, (f) supervising the production as an external assessor to test students, and $(\mathrm{g})$ the competence that has mastered the skill of students recorded in the passport.

The competency-based competency test model in VHS developed includes: (a) competence standards developed based on a combination of SKKNI automotive sector of light vehicle engine sub-sector with competency standard of graduates, (b) syllabus synchronized with work requirement in industry and done routinely every year, (c) learning component in VHS include: teachers become assessors independently, students carry out the material soft skills and progress reports in the form of skills passport, VHS has CBA center, and become professional certification agency independent, and (d) students implement prakerin focusing on clusters of competence, competency testing is done through a real job in the industry.

WBA carried out on VHS is a CBA that combines the learning process with the assessment process carried out during the students carry out industrial work practices by using patterns of students work on the real job.

\section{References}

Clark, L., \& Winch, C. (2007). Vocational education, international approaches, developments, and systems. Oxon: Routledge.

Dedi, S., Wiranto, A., \& Soenaryo. (2002). Sejarah pendidikan teknik dan kejuruan di Indonesia, membangun manusia produktif [Technique and vocational education in Indonesia, building productive people]. Jakarta: Departemen Pendidikan Nasional.

Depdikbud. (1997). Keterampilan menjelang 2020 untuk era global [Skills facing 2020 for global era]. Jakarta: Departemen Pendidikan dan Kebudayaan.

Depdikbud. (1999). Keputusan Menteri Pendidikan dan Kebudayaan Republik Indonesia nomor 323/U/1997 tentang penyelenggaraan pendidikan sistem ganda pada sekolah menengah kejuruan [Education and Culture Ministry of Republic of Indonesia No. 323/U/1997 on dual system for vocational school management]. Jakarta: Depdikbud.

Dewey, J. (1916). Democracy and education. New York: Dover Publications.

DiRanna, K., Osmundson, E., \& Topps, J. (2008). Assessment-centered teaching: A reflective practice. California: Sage Publishing.

Finch, C. R., \& Crunkilton, J. R. (1999). Curriculum development in vocational and technical education, planning, content, and implementation (5th ed.). Boston: Allyn \& Bacon.

Fletcher, S. (2000). Competence-based assessment techniques (2nd ed.) London: Kogan Page Limited.

Gall, M. D., Gall, J. P., \& Borg, W. R. (2007). Educational research, an introduction ( $8^{\text {th }}$ Ed.). Boston: Pearson Education.

Gonczi, A. (1998). Developing a competent workforce: Adult training strategies for vocational educators and trainers. South Australia: NCVER.

Gulikers, J. T. M., Runhaar, P., \& Mulder, M. (2017). An assessment innovation as flywheel for changing 
Work-based assessment at vocational high school in Indonesia

teaching and learning. Journal of Vocational Education \& Training, 1-20.

http://doi.org/10.1080/13636820.2017.1394353

Haines, C., Dennick, R., \& António, J., (2013). Developing a professional approach to workbased assessments in rheumatology. Best Practice \& Research Clinical Rheumatology, 27(2), 123-136.

https://doi.org/10.1016/j.berh.2013.02.006

Halliday-Wynes, S., \& Misko, J. (2012). Assessment issues in VET: Minimizing the level of risk. South Australia: NCVER.

Hawke, G., \& Oliver, L. (1998). Assessment in modern vocational education. Developing a competent workforce, adult learning strategies for vocational educators and trainers. South Australia: NCVER.

Hayes, K. (2012). Work-place based assessments. Obstetrics, Gynecology \& Reproductive Medicine, 22(7), 205-207. https://doi.org/10.1016/j.ogrm.2012.03.002.

Kelly, M. G. (2000). National educational technology standards for students, connecting curriculum and technology. Washington, D.C.: ISTE.

Lester, S. (2017). Reconciling activity-based descriptions of competence with professional work. Higher Education, Skills and Work-Based Learning, 7(4), 381-393. https://doi.org/10.1108/HESWBL-07-2017-0042

Miller, P. W. (2008). Measurement and teaching. Indiana: Patrick W Miller and Associates.

Prosser, C. A., \& Allen, C. R. (1925). Vocational education in a democracy. New York: Century.

Rauner, F. (2009). TVET curriculum development and delivery. In R. Maclean \& D. Wilson (Eds.), International handbook of education for the changing world of work, bridging academic and vocational learning (pp. 1579-1592). Springer Science+Business Media. https://doi.org/10.1007/978-1-4020-5281-1_106

Reeves, D. B. (2004). Making standards work: how to implement standard-based assessments in the classroom, school, and district ( $3^{\text {th }}$ ed.). Englewood: Advanced Learning Press.

SAQA. (2005). Guidelines for integrated assessment. Pretoria: SAQA.

Scott, L. J., Sarkees, M., \& Wircenski. (2004). Overview of career and technical education (3rd ed.). Illinois: American Technical Publishers, Inc.

Streumer, J. N. (2006). The effectiveness of OJT in the context of HRD. Berlin: Springer.

Thompson, J. F. (1973). Foundations of vocational education, social and philosophical concepts. New Jersey: Prentice-Hall, Inc. 
Santosa, B., \& Dwi, S. 